Jahangirnagar University J. Biol. Sci. 5(1): 87-93, 2016 (June)

Short communication

\title{
Acmella radicans (Jacq.) R.K. Jansen (Asteraceae) - a new angiosperm record for Bangladesh
}

\author{
M. Mahfuzur Rahman, Saleh Ahammad Khan, Gazi Mosharof Hossain*, \\ Md. Jakaria ${ }^{1}$ and Md. A. Rahim \\ Department of Botany, Jahangirnagar University, Savar, Dhaka, Bangladesh
}

Key words: Acmella radicans, new record, angiosperm, Bangladesh.

A floristic survey was conducted throughout the Pablakhali Reserve Forests of Rangamati district of Bangladesh from May, 2014 to December, 2015. During this survey the representative specimens of almost all vascular plants available in this virgin forest were collected. After the critical taxonomic studies on the specimens of the family Asteraceae, few were finally identified as Acmella radicans (Jacq.) R.K. Jansen, which has been reported here as a new angiospermic record for Bangladesh.

The genus Acmella Rich. ex Pers., first described by Richard (1807), was previously considered as Spilanthes sect. Acmella (Rich. ex Pers.) DC., one of the two sections of the genus Spilanthes Jacq. belonging to the family Asteraceae (Compositae) under the tribe Heliantheae and the sub-tribe Ecliptinae based mainly on the nature of the head. Spilanthes sect. Spilanthes was recognized with radiate heads and Spilanthes sect. Acmella with discoid heads (Cassini, 1822; De Candolle, 1836; Moore, 1907). Later on, the comparative morphological and chromosomal evidences suggested for the recognition of Acmella Rich. ex Pers. and Spilanthes Jacq. as distinct genera (Jansen and Stuessy, 1980; Jansen, 1981), which was endorsed by Pruski (1997), Flora of China Editorial Committee (2011) and Davidse et al. (2016), though these two genera are also viewed as taxonomically confusing (Paulraj et al., 2013). The detailed systematics of Acmella was published by Jansen (1985) who distinguished the genus Acmella from Spilanthes by its certain morphological characters, viz., petiolate leaves, radiate heads and dimorphic achnes without distinct corky margins at maturity. The genus Acmella comprises 30 species including nine infraspecific taxa that are mainly distributed in the tropical and subtropical regions around the world (Jansen, 1985; Mabberley, 2005; Das, 2013). The genus is native to the Americas and introduced in Asia, Africa, Pacific Islands and Australia.

\footnotetext{
${ }^{1}$ Department of Environmental Science and Management, North South University, Dhaka, Bangladesh

* Corresponding author. E-mail: gazibotju@gmail.com
} 
The genus Acmella of Bangladesh has been incautiously described as Spilanthes (e.g., Khan 1992; Ahmed et al., 2008; Rahman et al., 2008) even after its recognition as a distinct genus by Jansen and Stuessy (1980) and Jansen (1981; 1985). The three species of Spilanthes, viz., Spilanthes culva DC, S. oleracea L. and Spilanthes paniculata Wall ex. DC described from Bangladesh (Khan 1992; Ahmed et al., 2008; Rahman et al., 2008) were synonymized under Acmella calva (DC.) R.K. Jansen (Syn.), Acmella oleracea (L.) R.K. Jansen (Syn.) and Acmella paniculata (Wall. ex DC.) R.K. Jansen (Syn.), respectively.

The species Acmella radicans, commonly known as 'White spot-flower plant', is native to Central and South America and widespread in New and the Old world tropics or warm climate areas around the world (Sivarajan \& Philip, 1984; Stevens et al., 1998; Raja et al., 2013). This species or its basionym Spilanthes radicans Jacq. has never been reported from the floristic area covering the present territory of Bangladesh by any literature before (viz. Hooker, 1879; Prain, 1903; Heinig, 1925; Raizada, 1941; Khan \& Banu, 1969; Khan, 1992; Pasha \& Uddin, 2013; Rahman et al., 2015 etc.; Ahmed et al., 2008; Rahman et al., 2008), though it has been reported from several areas of India (e.g., Sivarajan and Philip, 1984; Bhowmik et al. 2013; Raja et al., 2013; Jagtap \& Bachulkar, 2015; Patel et al., 2015). In this study, Acmella radicans (Jacq.) R.K. Jansen has been reported for the first time from Bangladesh following a critical taxonomic investigation on the specimens of Asteraceae collected from the ethnic homestead area of Parachara hill of Pablakhali Reserve Forest belonging to Rangamati district and relevant literatures. The specimens are presently housed at Jahangirnagar University Herbarium (JUH), Savar, Dhaka, Bangladesh. The detailed description and illustration of the species based on herbarium material are given below.

Acmella radicans (Jacq.) R.K. Jansen, Syst. Bot. Monogr. 8: 69-70, f. 18 (1985). Spilanthes radicans Jacq. Collect. Bot. Chem. Hist. Nat. 11(3): 1714 (1804). Ceratocephalus exasperatus (Jacquin) Kuntze, Revis, gen. pl. 1: 326 (1891). -TYPE: Venezuela. Collector unknown (holotype not located; the illustration, t. 584, in Jacquin's later work, Icones plantarum rariorum, vol. 3, 1792, fixes the application of this name; Jansen 1985:69). Acmella debilis (Kunth) Cass. (1822) and Spilanthes debilis Kunth. (1820). (Photograph 1 and Fig. 1).

Erect herbs, 30 to $90 \mathrm{~cm}$ tall. Stems terete, minutely pubescent, with few ascending branches. Leaves simple, opposite; petioles $1-2.5 \mathrm{~cm}$ long, sparsely pubescent; leaf blades $1-7 \times 0.5-3.5 \mathrm{~cm}, 3$-nerved, ovate to widely oblong, abaxially and adaxially isolatedly puberulous to pubescent, apically acute, basally obtuse, marginally dentate or serrate and minutely ciliate. Heads few to many, axillary or terminal, $8-12 \times 4-6 \mathrm{~mm}$, white, discoid, usually cone-like, occasionally sub-globose, turning elongate-ovoid at maturity; peduncles $1.5-7 \mathrm{~cm}$ long, sparsely pubescent; receptacles columnar or spindle-shaped, glabrous, 5-7 mm long, slightly ciliate at the apex. Involucral bracts two-seriate; bracts of outer series 6, 4-5.5 mm long, 4-5 nerved, broadly ovate, green, marginally ciliate, apically obtuse, adaxially sparsely puberulous to pubescent; bracts of inner series 4-5, 3.5-4.5 mm long, 3-nerved, pale green, widely linear to narrowly oblong, scabrid, 
marginally ciliate, apically subulate-obtuse. Flowers per head numerous, discoid, hermaphrodite. Corollas 4-lobed, rarely 5-lobed, 0.75-1 mm long, white to greenish white; corolla tubes 1.5-2 mm long, papillose, base bulbous; corolla lobes 1-1.25×1-1.4, ovate, spreading, glabrous, marginally entire, apically obtuse. Styles 1-1.5 mm long, arms short, truncate, densely papillose. Stamens 4, $1.5 \mathrm{~mm}$ long, syngenesious, anthers 0.5-0.6 $\mathrm{mm}$ long, brown-black, filaments 0.9-1 mm long.

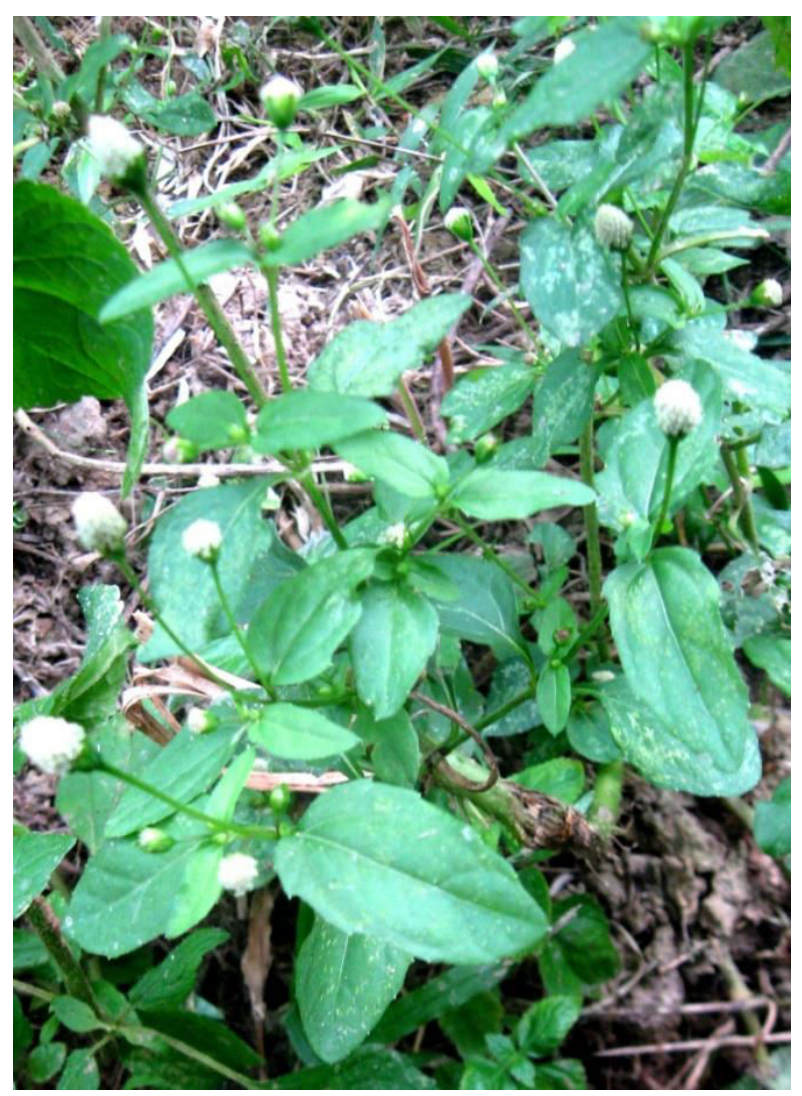

Photograph 1. Acmella radicans

Pappus of 2-3, 1.25-1.5 mm long bristles, persistent. Achenes 2-2.5×1 mm, black, dimorphic, marginal ones trigonous, inner ones laterally compressed or flattened, ellipsoid, obcordate, without evident cork-like margin, outer surface excluding the margins glabrous or sparsely covered with few tuberculae, margins straminous and ciliate, brownish-black, with straight-tipped 1-1.5 mm long hairs, inner bracts partially covering the achenes numerous, 2.25-2.75 mm long, boat-shaped, semi-transparent, light-brown.

Flowering and Fruiting: August-January.

Ecology: In shady waste place, along road-side habitats, growing in association with Acmella culva, Ageratum conyzoides L., Alternanthera sessilis (L.) R. Br. ex Roem. \& Schult, Axonopus compressus (Sw.) P. Beauv., Cynodon dactylon (L.) Pers., Eleusine indica (L.) Gaertn. and Paspalum longifolium Roxb. etc. 


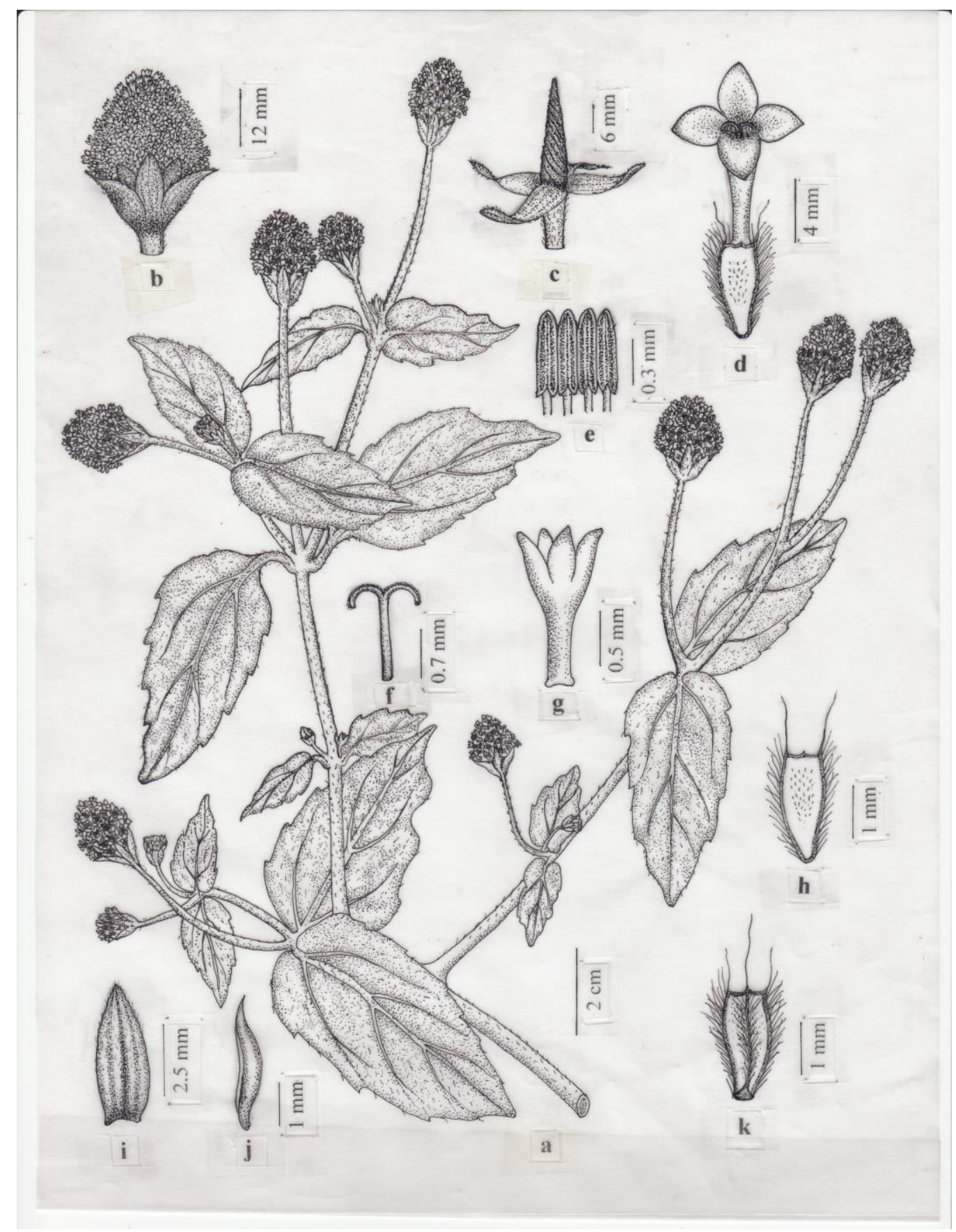

Fig. 1. Acmella radicans: (a) a flowering branch, (b) a head, (c) a receptacle with outer bracts, (d) a flower, (e) stamens (f) a style, (g) a corolla, (h) a laterally compressed achene, (i) an outer involucral bract, (j) an achene-covering inner bract, (k) a trigonal achene 
Propagation: Through seeds and stem cutting.

Distribution: Native in Central and South America and becoming widespread (Hyde et al., 2016).

Representative specimen examined: Rangamati: Pablakhali Reserve Forest, Parachhara, 25.12.2015, G.M. Hossain GMH-1103 (JUH); M.A. Rahim MAR-3007 (JUH).

Notes: The specimens of Acmella radicans (Jacq.) R.K. Jansen examined and its population found in the study area belongs to the variety A. radicans (Jacq.) R.K. Jansen var. radicans. This variety is distinct from another variety of the species $A$. radicans var. debilis (Kunth) R.K. Jansen by its discoid heads and achenes usually without evident corky margins at maturity in contrast to radiate heads and evident corky margins of achenes of A. radicans var. debilis (Jansen, 1985; Jagtap et al., 2015).

Acmella var. radicans seems similar to and often confused with Acmella paniculata from which it is distinctive by its axillary or terminal cluster of 2-3 heads, 4-merous white florets, and achenes lacking an evident corky margin at maturity and with or without a few tuberculae on the surfaces. In contrast, A. paniculata has solitary terminal or axillary heads, usually 5-merous, sometimes 4-5-merous yellow florets, and mature achenes with an evident cork-like margin and moderately to densely tuberculate surfaces.

Uses: Acmella radicans produces at least seven alkamides (Cortez-Espinosa et al., 2011). The uses of the Acmella radicans in traditional medicine can be generally summarized as follows: (a) relieve toothache and affections of throat and gums as well as to paralyse the tongue; (b) flower heads are known as a popular remedy for stammering children. A tincture made from the flower heads is also substituted for a tincture of pyrethrum for the treatment of inflammation in the jaw-bone; (c) seeds are regarded as a stimulant and sialagogue common cold, fever, and cough; (d) whole plant is boiled in water and the liquid as well as the solid are administered against dysentery; (e) a decoction is used as a diuretic and lithotriptist agent and employed as a bath against rheumatism, but also as a lotion against scabies and psoriasis; (f) juice of the plant is effective as a vulnerary and the pounded herb as a poultice to dress wounds and (g) roots are used in several parts of India as a purgative, while the whole plant is a fish poison (CSIR, 1982; Rios-Chavez et al., 2003).

Acknowledgement: Authors gratefully acknowledge the SRCWP project of World Bank for the financial support to conduct the floristic survey and recording of the phytodiversity in Pablakhali Reserve Forest at Rangamati district, Bangladesh.

\section{REFERENCES}

Ahmed, Z.U., Begum, Z.N.T., Hassan, M.A., Khondker, M., Kabir, S.M.H., Ahmed, M., Ahmed, A.T.A., Rahman, A.K.T. and Haque, E.U. (eds.). 2008. Encyclopedia of Flora and Fauna of Bangladesh, Vol.-6. Asiatic Society of Bangladesh, Dhaka. pp. 340-341. 
Bhowmik, S., Ghosh, S. and Datta, B.K. 2013. Acmella radicans (Jacquin) R.K. Jansen [Asteraceae] - A New Distributional Record for Tripura in North East India. Pleione 7(2): 574 - 578.

Cassini, H. 1822. Spilanthes. In: Dictionnaire des sciences naturelles, by H. Cassini, 24: 328- 331. Paris: Le Normant.

Cortez-Espinosa, N., Aviña-Verduzco, J.A., Ramírez-Chávez, E., Molina-Torres, J., and RíosChávez, P. 2011. Nat Prod Commun., 6(6):857-61.

CSIR, 1982. The wealth of India Vol. X, A dictionary of Indian Materials and Industrial Products Raw Material, Publication and Information Directorate CSIR, New Delhi, p.11.

Das, K.K. 2013. A new distributional record of Acmella ciliata (Kunth) Cassini [Asteraceae] from Assam, India. Pleione 7(1): 258 - 261

Davidse, G., Sousa-Peña, M., Knapp, S. and Cabrera, F.C. 2016. Asteraceae. 5(2): ined. In: G. Davidse, M. Sousa Sánchez, S. Knapp and F. Chiang Cabrera (eds.) Fl. Mesoamer.. Missouri Botanical Garden, St. Louis.

DeCandolle, A.P. 1836. Spilanthes. In: A.P. de Candolle (ed), Prodromus systematis naturalis regni vegetables. Vol. 5. Treuttel and Wurtz, Paris. pp. 620-626.

Flora of China Editorial Committee. 2011. Flora of China (Asteraceae). 20-21: 1-992. In: C. Y. Wu, P. H. Raven \& D. Y. Hong (eds.) Fl. China. Science Press \& Missouri Botanical Garden Press, Beijing \& St. Louis.

Heinig, R.L. 1925. List of plants of Chittagong Collectorate and Hill Tracts. The Bengal Government Branch Press, Darjeeling, India. pp. 1-84.

Hooker, J.D. 1879. The Flora of British India Vol. II. L, Reeve \& Co., 5 Henrietta Street, Covent Garden, London.

Hyde, M.A., Wursten, B.T., Ballings, P. and Coates Palgrave, M. 2016. Flora of Zimbabwe: Species information: Acmella radicans var. radicans. http:/www.zimbabweflora.co.zw/ speciesdata/species.php?species_id=212680, retrieved 15 August 2016.

Jagtap, D.G. and Bachulkar, M. 2015. Acmella radicans var. debilis (Asteraceae): A new varietal record for Asia. Rheedea, 25(1): 39-43.

Jansen, R.K. 1981. Systematics of Spilanthes (Compositae: Heliantheae). Syst. Bot. 6: 231-257.

Jansen, R.K. 1985. The systematics of Acmella (Asteraceae - Heliantheae). Syst. Bot. Monogr. 8: $1-115$.

Jansen, R.K. and Stuessy, T.F. 1980. Chromosome counts of Compositae from Latin America. Amer. J. Bot. 67: 585-594.

Khan, M.S. and Banu, F. 1969. A taxonomic report on the angiospermic flora of Chittagong Hill Tracts-1. J. Asiat. Soc. Pak. 14(2): 217-222.

Khan, S.A. (1992). A taxonomic study on the Compositae of the eastern region of Bangladesh. (M.Sc. Thesis, unpublished). Department of Botany, Jahangirnagar University, Savar, Dhaka.

Mabberley, D.J. 2005. The Plant-Book. Cambridge University Press, U.K.

Moore, A.H. 1907. Revision of the genus Spilanthes. Proc. Amer. Acad. Art. Sci. 42: 521-569.

Pasha, M.K. and Uddin, S.B. 2013. Dictionary of plant names of Bangladesh (Vascular plants). Janokalyan Prokashani, Chittagong, Bangladesh. 434 pp.

Patel, K., Vyas, V. and Pandya, A.V. 2015. Acmella radicans (Jacquin) R.K. Jansen [Asteraceae] A New Record for Gujarat State, India. Life Sciences Leaflets, Vol. 62, Page 43-47, ISSN 2277-4297 (Print) 0976-1098 (Online). http://lifesciencesleaflets. ning.com.

Paulraj, J., Govindarajan, R. and Palpu, P. 2013. The Genus Spilanthes Ethnopharmacology, Phytochemistry, and Pharmacological Properties: A Review. Advances in Pharmacological Sciences. 2013: 1-22. http://dx.doi.org/10.1155/2013/510298.

Prain, D. 1903. Bengal Plants. Vol. 1 and 2. Reprint Edition 1963. Calcutta, India. 
Pruski, J.F. 1997. Asteraceae. 3: 177-393. In: J. A. Steyermark, P. E. Berry \& B. K. Holst (eds.) Fl. Venez. Guayana. Missouri Botanical Garden Press, St. Louis.

Rahman, A.H.M.M., Alam, M.S., Khan, S.K., Ahmed, F., Islam, A.K.M.R. and Rahman, M.M. 2008. Taxonomic Studies on the Family Asteraceae (Compositae) of the Rajshahi Division. Research Journal of Agriculture and Biological Sciences, 4(2): 134-140.

Rahman, M.S., Hossain, G.M., Khan, S.A. and Uddin, S.N. 2015. An annotated checklist of the vascular plants of Sundarbans mangrove forest of Bangladesh. Bangladesh J. Plant Taxon. 22(1): 17-41.

Raizada, M.B. 1941. On the flora of Chittagong. Indian Forester. 67: 245-254.

Raja, P., Dhathchanamoorthy, N., Kala A. and Soosairaj, S. 2013. Spilanthes radicans Jacq. (Asteraceae) A New Record to Tamilnadu, India, Int. J. Int sci. Inn. Tech. eISSN 22781145, Sec. A, 2 (6):34-35.

Richard, L.C. 1807. Acmella. In: Synopsis Plantarum, by C. Persoon, Paris. Pp. 472 - 473.

Rios-Chavez, P., Ramirez-Chavez, E., Armenta, C. \& Torres, M., J. Plant, 39, 2003, 37-41.

Sivarajan V.V and Philip, M. 1984; Notes on three new immigrant species of Spilanthes Jacq. (Asteraceae) in india and the identity of the common 'tooth - Ache plant'. Ancient Science of Life, 3(3):169-173.

Stevens, W.D., Uooa, Ulloa, C., Pool, A. and Montiel, O.M. 1998. Flora de Nicarague chap. 85 Missuri, Botanical Garden Press, St. Louis, M.O. Pp. 284. 